\title{
СПИСОК СОКРАЩЕНИЙ
}

\begin{tabular}{|c|c|}
\hline СЮР & — Вооруженные силы на юге России \\
\hline ЖМнП & — Журнал министерства народного пия \\
\hline КИГИ РАН & — Калмыцкий институт гуманитарных исследований РАН \\
\hline СИА & $\begin{array}{l}\text { - Краткие сообщения о докладах и полевых исследованиях } \\
\text { Института археологии АН СССР. }\end{array}$ \\
\hline КСИИМК & $\begin{array}{c}\text { - Краткие сообщения о докладах и полевых исследованиях } \\
\text { Института истории материальной культуры АН СССР. }\end{array}$ \\
\hline МАД & - Материалы по археологии Дагестана. \\
\hline IAK & - Материалы по археологии Кавказа. \\
\hline ИИА & - Материалы и исследования по археологии СССР \\
\hline HA PK & - Национальный архив Республики Калмыкия \\
\hline $\mathrm{PBC}$ & — Революционный военный совет \\
\hline РГВА & — Российский государственный военный архив \\
\hline PККА & — Рабоче-крестьянская Красная армия \\
\hline РФ ИИАЭ & $\begin{array}{l}\text { - Рукописный фонд Института истории, археологии и } \\
\text { этнографии ДНЦ РАН }\end{array}$ \\
\hline $\mathrm{CA}$ & - Советская археология. \\
\hline СГАИМК & $\begin{array}{l}\text { - Сообщения Государственной академии истории } \\
\text { материальной культуры. }\end{array}$ \\
\hline $\mathrm{CЭ}$ & - Советская этнографии. \\
\hline Тр. гим & — Труды Государственного исторического музея. \\
\hline Тр. ЧИ НИИ & $\begin{array}{l}\text { - Труды Чечено-ингушского научно-исследовательского } \\
\text { института }\end{array}$ \\
\hline ял & $\begin{array}{l}\text { - Ученые записки Института истории, языка и литературы } \\
\text { Дагестанского филиала АН СССР. }\end{array}$ \\
\hline
\end{tabular}

